rev.relac.int.estrateg.segur.10(1):41-63,2015

\title{
THE EVOLUTION OF SECURITY IN SOUTH AMERICA: A COMPARATIVE ANALYSIS BETWEEN COLOMBIA AND BRAZIL"
}

\author{
Luis Fernando Vargas-Alzate ${ }^{* *}$ \\ Santiago Sosa Noreña ${ }^{* * *}$ \\ Héctor José Galeano David ${ }^{* * * *}$
}

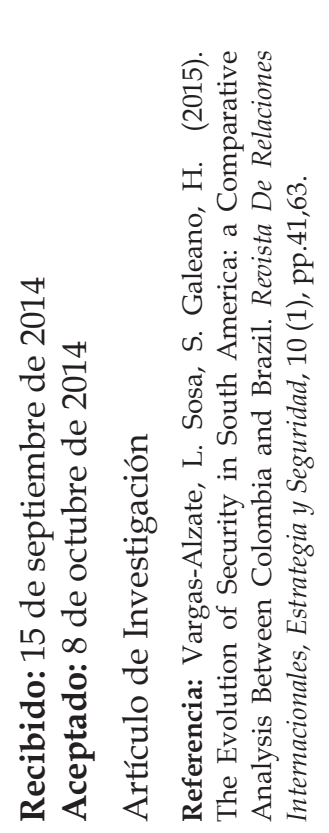

\begin{abstract}
This article studies the evolution of security in South America by comparing the advances of two of its most characteristic cases, Colombia and Brazil, in their transition from traditional security models to the application of the concept of human security. Through a historical analysis of both cases and a timeseries analysis of their soldiers per inhabitant, military quality, military and social spending, and human development, the authors conclude that human security has taken a notable importance in the development plans and state programs
\end{abstract}

This paper is based on the final outcomes provided by the research project "International Relations between Colombia and Brazil during the beginning of the 21 century", supported by Universidad EAFIT (Medellin) and Universidad de la Costa (Barranquilla), and with participation of all authors.

** Magister in Political Studies. Academic Coordinator of IR academic area, Universidad EAFIT. Ivargas3@eafit.edu.co

*** Magister in International Business from the Universidad EAFIT. ssosanor@ eafit.edu.co.

**** PhD. candidate of Social Sciences, Universidad del Norte.hectorgaleano@ yahoo.com. 
in both countries. However, they present an opposite trend regarding militarization: Brazil is becoming more and more demilitarized (although its army is being improved constantly, explained by the country's high military spending), whereas Colombia is becoming more and more militarized in order to confront its internal conflict. In spite of this, Colombia's human development rivals that of Brazil, yet both are lower than the region's average, which means that although the focus on human security is being implemented, the advance has been slow and differences between the two cases are smaller than expected.

Keywords: Human Security, South America, Colombia, Brazil, Foreign Policy.

\section{LA EVOLUCIÓN DE LA SEGURIDAD EN SUDAMÉRICA: UN ANÁLISIS COMPARATIVO ENTRE COLOMBIA Y BRASIL}

\section{RESUMEN}

Estudia la evolución de la seguridad en Suramérica comparando los avances dados en dos casos característicos para la región, Colombia y Brasil, en relación con la transición de modelos de seguridad tradicionales hacia la aplicación del concepto de seguridad humana. Análisis histórico de casos y el estudio de series temporales tales como el número de soldados por habitante, su calidad militar, el gasto social y castrense, y el desarrollo humano, los autores concluyen que la seguridad humana ha tomado una importancia notable en los planes de desarrollo y los programas estatales de ambos países. Sin embargo, presentan una tendencia opuesta con respecto a la militarización: Brasil menos militarizado (aunque su ejército se está mejorando constantemente, hecho que se explica por el elevado gasto militar del país); Colombia más militarizado con el fin de enfrentar su conflicto interno. Puede señalarse que el desarrollo humano de Colombia rivaliza con el de Brasil; no obstante ambos casos estén por debajo del promedio regional. Entonces, es factible concluir que, si bien se está aplicando el enfoque de la seguridad humana en ambas naciones, el avance ha sido lento y las diferencias entre ellas son menores a lo esperado.

Palabras clave: Seguridad Humana, Suramérica, Colombia, Brasil, Política Exterior.

\section{A EVOLUÇÃO DA SEGURANÇA NA AMÉRICA DO SUL: UMA ANÁLISE COMPARATIVA ENTRE A COLÔMBIA E O BRASIL}

\section{RESUMO}

Este artigo estuda a evolução da segurança na América do Sul, comparando os avanços de dois de seus casos mais característicos, a Colômbia e o Brasil, em sua transição de modelos tradicionais de segurança à aplicação do conceito de segurança humana. Por meio de uma análise histórica 
de ambos casos e uma análise de séries temporais de seus soldados por habitante, qualidade militar, as despesas militares e sociais e o desenvolvimento humano, os autores concluem que a segurança humana tem tomado uma notável importância nos planos de desenvolvimento e programas do Estado em ambos países. No entanto, eles apresentam uma tendência oposta em relação à militarização: o Brasil está se tornando mais e mais desmilitarizado (embora o seu exército esteja sendo melhorado constantemente, explicado pelo alto gasto militar do país), enquanto que a Colômbia está se tornando mais e mais militarizada para enfrentar seu conflito interno. Apesar disto, o desenvolvimento humano da Colômbia é similar ao do Brasil, mas ambos são inferiores do que a média da região, o que significa que, embora a segurança humana seja implementada, o avanço tem sido lento e as diferenças entre os dois casos são menores do que o esperado.

Palavras-chave: Segurança Humana, América do Sul, Colômbia, Brasil, Política Externa.

\section{INTRODUCTION}

Recently, international security studies have changed their focus from the nation (state) to the individual (Thomas \& Tow, 2009). The center of the current debate is not quantitative in relation to the number of soldiers that defend a given society, nor is it about how much money is invested in each soldier so that he or she may have exceptional results in the field. Rather, security studies demand that the great discussions be centered on the state's institutional obligations towards its citizens. Hence the concept and saliency of human security (Oberleitner, 2005; Thomas \& Tow, 2009). The present study will illustrate the application of this concept in two South American countries, Colombia and Brazil.

It is precisely in this aspect that this academic exercise holds its value: there are few analyses of the application of human security in South America. This is surely down to the general scarcity of policies that clearly strengthen security, not from the defense point of view (the traditional notion of security) but from the satisfaction of the necessities of the human being (human security) as is argued below. In addition, the focus of this work is novel because it presents a comparative analysis of two key regional cases, which for distinct reasons represent the most important South American players in defense spending.

The central argument here is that advances in the implementation of the most recent concepts of security (human security) in South America, specifically in Colombia and Brazil, are at a disadvantage regarding other geographical areas. Despite the number of speeches, debates and academic literature oriented towards human security in South America, what is defined in politics is bigger than what is actually applied. Nevertheless, of the two countries studied here, Brazil has led the processes and surpasses Colombia in implementation of human security policies, although the two cases show lower human development than the 
South American average. As such, thus study aims to offer the foundation of a necessary body of research carefully analyzing the multiple variables that each government in the region applies to the understanding of security. The next section deals with the methodological approach to this study.

\section{METHODOLOGY}

For the effects of this study, the human security concept that will be used is the integral protection of the people, which includes both traditional security (i.e. physical integrity) and integral development of the human being. In order to evaluate human security in the two cases, the analysis takes into account several variables with which the authors assess the governments' performance in providing the individuals with physical security, health, education and economic welfare, the latter three gathered in the human development index. This means that the study has limitations in the assessment of human security, which sets the path for future research, as will be discussed in the concluding remarks.

This study presents a historical analysis of Colombia and Brazil and a comparative analysis using a cross-sectional time series analysis. It is, therefore, a mixed approach, as both qualitative and quantitative tools are used (although, the first will be more often used than the latter). Regarding the first, the paper presents a study of the actions in foreign policy of both countries in the last decades related to security, in contrast with their domestic pressures and changes. With the second method, the time series analysis focuses on indicators of military capacity and human development.

The indicators used are the following: The Composite Index of National Capabilities (CINC) of the Correlates of War Project is the result of the evaluation of five sub-indexes: iron and steel production, energy consumption, total population, urban population, military personnel and military expenditure (Singer, 1987). By using three of these sub-indexes, two indicators can be formed. The first is military quality, defined as dollars invested per soldier, and the second is soldiers per 10,000 inhabitants. The data are available from the 19th century until 2007.

To compare the focus on traditional security with the focus on human security in both states, the dataset of the World Bank (2012) was used. From this dataset we have taken three variables: military expenditure, public spending on health and public spending on education, and all three as a percentage of GDP. Finally, we contrast the latter variable with the Human Development Index (HDI) developed by the UNDP (2012). This index is calculated using four variables: life expectancy at birth, average instruction years, expected instruction years and GDP per capita. From 1980 to 2000, the index is available for every five years. From 2005 onward, the index is available on a yearly basis and it also accounts for the population's inequality by using the Atkinson index. 


\section{THEORETICAL APPROACH TO THE CONCEPT OF SECURITY: THE INTERNATIONAL CONTEXT}

The changing circumstances of the post-Cold War period produced new discussions, led by the Copenhagen School (after seminal Buzan's work (1983): People, states and fear), in which the concept of security was broadened: it was no longer a matter of national defense, but of a plethora of security concerns. Thus, concludes Baylis (2008), the contemporary debates focus not only on the application but also on the reach of the concept itself. The United Nations Development Program (UNDP) (1994), for instance, worked with the specific aim of overcoming the traditional definition of security, deeply linked to defense, when it proposed the concept of human security. ${ }^{1}$

The change from a reduced and limited perspective of security, defined exclusively in military terms (defense), towards a more diversified and ample one (human security), is a natural response to the shifting challenges that societies face nowadays. However, such a change is evidenced fundamentally in the relations between advanced societies that have completely overcome armed conflict between them (Inglehart \& Norris, 2012). This process has naturally been closely followed by academicians. The work of Thomas and Tow (2009), for instance, focused on going beyond traditional notions of security and inquiring about the key generators of security in societies. Oberleitner's (2005) analysis, on the other hand, tries to integrate human security into international law studies.

The new security perspectives and their applications have made governments, policymakers, policy communities and IR scholars (re)think existing policy measures. Moreover, it is notable that, for contemporary societies, advanced or not, human security has become quintessential to peaceful coexistence, whereas defense and military prowess are further and further away from the demands of many societies in today's international system. Later on in this text, the possibilities of the transformation of the application of security in the two cases will be analyzed. Prior to that, the newest perspectives will be studied more deeply.

\section{NEW SECURITY ORIENTATIONS}

Nowadays, the emphasis on human security makes this concept a fundamental tool to understanding the newest patterns of conflict and defense in the post-Cold War era, and it

1. The UNDP has championed human security as a mechanism that encompasses a broad perspective on what makes an individual safe. It is a universal concern and its components are interdependent. Moreover, it gives prominence to prevention rather than intervention. UNDP found seven sources of insecurity: political, economic, environmental, food, personal, community and health (UNDP, 1994). 
also enables the international community (especially the Global North) to build an articulated and coherent answer to the challenges posed by a problematic and conflictive Global South (Christie, 2010). From this it follows that the conceptualization and practice of human security is more important with each passing day. Nevertheless, it is important to note that the concept possesses a dangerous duality: as Christie puts it, its application has enabled the satisfaction of needs in marginalized communities in the framework of existing political and economic structures but, at the same time, it has been used to justify an increase in the number and range of interventions by the traditional international actors.

This inconvenience is part of the hypothesis that motivates this study. In Brazil and Colombia, both at the margins and the center of government, there are difficulties in differentiating the contemporary and traditional applications of security, even though the two have very different security implications and agendas. This topic will be explained further when regional security is analyzed. For now, and from a broader perspective, it is essential to point out that the new security orientation has been developed in multiple ways regarding its application in foreign policy, which generates disagreement in defining human security and its place in policymaking (McCormack, 2008). We recommend the Kegley \& Raymond's work (2011) for this point. It is a complete and seminal textbook for studying this discrepancy.

Ever since the UNDP defined the concept in 1994, it has been difficult for state institutions to change their security policies, even more so because risk assessment becomes extremely complex when the perceptions of what makes an individual safe are taken into account. Indeed, what could make a citizen safe, or what he or she believes could make him or her safe, can greatly differ from his or her government's assessment. Moreover, the focus on the citizen brings an added level of complexity to the application of security because policy communities rarely have the necessary resources to reach micro-levels of analysis and policy implementation (Thomas \& Tow, 2009).

The perception and variables analyzed generically in the global scenario are closely related to advances in regional scenarios. Within the framework of the new regionalism, as presented by Robert Kelly in his Security Theory in the New Regionalism (2007), it is fundamental to ground general theory in specific geographic regions, especially taking into account security complexes. Therefore, what has been developed so far regarding human security will now be analyzed in the specific context of Latin America and South America.

\section{THE REGIONAL CONTEXT}

From a theoretical perspective, two variables have played a relevant role: the concept of region and, as a consequence of the first, the so-called security complexes. Buzan \& Wæver (2003) have developed an interesting conceptualization of what a region is. On the one hand, the scope of the region and its members is defined geographically; on the other hand, although they don't represent an actor as such in the international system, they do possess an identity, 
which allows the study of a region to be framed in particular ontological terms. In the case of South America, both scope and identity can be defined given the historical, social, cultural, religious and idiomatic links that go back to the colonization of the continent and make this region an integral unit of analysis.

Another variable, determinant in the concept of region, is founded on each country's decisionmaking process regarding foreign policy, which can affect the neighborhood and are insufficient in solving regional problems that actually require multilateral efforts (Lemke, 2010). Hence, topics such as the Amazon affect the region in general and may thus become a destabilizing force in the South American concert.

In line with the above, security becomes an essential factor of stability for the region's members. Buzan \& Wæver (2003) argue that security complexes are characterized by a group of units whose main processes of securitization or de-securitization ${ }^{2}$, or both, are so intertwined that they cannot reasonably be analyzed or resolved independently.

Moreover, the traditional singular notion of the security dilemma has lately transformed into a diversity of security dilemmas that have opened the way, as Jennifer De Maio (2006) explains, for the emergence of new actors in regional governance and peace keeping. De Maio explains how, with the new approaches to regional security, it becomes possible to note the direct influence of both traditional and new organizations that act as mediators in problematic zones, both in conflict prevention and conflict resolution.

Just as it has occurred with the Union de Naciones Suramericanas (UNASUR) in South America and with other, broader organizations in Latin America, the new approach to security has made Latin America more peaceful than in the past. This may be considered a consequence of the application of the most recent security proposals. This new period is studied by Andrew Hurrell (1998) when he says that despite of a lot of variables for analyzing security in South America, it is possible to indicate that the region has become more stable and pacific. ${ }^{3}$ It is thus important to take into account several actions of the American states in this matter, of which a prime example is the Security Declaration of the Organization of American States (OAS) in 2003 in which the key principles for regional coexistence are laid out, in harmony with the UN Charter.

Indeed, some comparative studies have noted that Latin America is more peaceful vis-à-vis other regions of the world. Flemes and Nolte (2010) conclude that the region is in stable and

2. According to Ole Waever's book Securitization and desecuritization (1995), "securitization is understood as a political practice that allows the elites, acting on behalf of the State, to claim special rights of defense to point out something as a threat" (Tickner, 2004: 14).

3. However, it is clear that the region has many challenges to be really stable. According to Hurrell (1998: 546), "it is [this] combination of interdependence and inequality that makes regional security management so difficult." 
peaceful conditions, confirming Hurrell's (1998) view. Based on their statistical analysis, only four interstate conflicts occurred during the 90s in Latin America, whereas 16 have occurred in Africa, nine in Asia, nine in the Middle East and eight in Europe. Moreover, governments in Latin America, and especially in South America, have a preference for peaceful means of conflict resolution. Although it has been said that Latin America now has a very low military intensity, for the purpose of this study it is of the essence to focus on the sub region in which Colombia and Brazil are located: South America.

\section{THE SOUTH AMERICAN SCENARIO}

South America has advanced in strengthening peaceful conflict resolution tools in order to face the new realities of the current international context. As a consequence of the most recent integration schemes, Miller (2005: 248) argues, "the sub region has become less violent and more inclined towards peaceful conflict resolution mechanisms". There is, for instance, some evidence that the lack of interstate conflict is explained by the current integration structure anchored in the institutional scheme of UNASUR.

Moreover, this organization has formed the South American Defense Council that exerts influence in military topics, and the regional tendency towards change is evident: according to Ezequiel Gustavo Polverini (2010), in many countries of the region the state has stopped being the subject of preferential guardianship, giving way to the prominence of individuals, groups and societies. In this way, the security of the state is not an end in itself, but a means to guarantee the security of its inhabitants.

Thus, human security is nowadays a concept of the utmost importance in South America. Indeed, in her recent analysis, Bertha García (2010) argues that in the current conceptual turn the protection of human rights has surpassed the defense issues, strictly speaking, in prominence. In relations between Colombia and Brazil, some advances in this direction are notable, as it is shown in the next sections. Through the historical analysis of both cases and the statistical analysis of their armed forces and human development, the application of security will be analyzed.

\section{EVOLUTION OF SECURITY IN BRAZIL}

Both internal and external realities have exerted a strong influence in the development and evolution of the concept of security in Brazil. Two opposite poles can be found within the internal reality of this country: first, a long period of military dictatorship and second, a consolidating democracy that grows stronger with diverse social and economic reforms implemented during the present century. Externally, Brazil is a country that projects itself as a regional power and that has inserted itself in the international arena through strategies of foreign policy based on soft 
power. In that order of ideas, authors such as Costa (2004), Flemes \& Nolte (2010) and Cepik \& Ramirez (2004), make clear the projection of Brazil as average power. ${ }^{4}$

\section{FROM DICTATORSHIP TO DEMOCRACY}

The Brazilian dictatorship started with a coup d'état orchestrated by the military, led by the general Castelo Branco, in alliance with a sector of the economically powerful class. The quest for economic dominion and the alliances with international investors and companies became the most relevant factors motivating the coup, through which the military suffocated student and union movements that started to manifest in the 60s. This paved the way towards agrarian reform and the limitation to the outflows of capital. This would have a deep effect in the interests of foreign investors, which were protected until that time (Sader, 2010).

According to Virginia Fontes (2007), there were three stages in social and political thought in Brazil during the dictatorship, which would later on move towards the dismantling of the authoritarian regime. The first stage went from 1974 to the beginning of the 80s, which is defined as a regime that opened the possibilities to return to democracy, the second was short lived transition period between dictatorship and democracy, and the last stage was the reinstatement of democracy between 1985 and 1989, which is called the New Republic. In this line, the development of democratic ideas can be accounted for with the writings of two authors: Fernando Henrique Cardoso and Wanderley Guilherme dos Santos (Fontes, 2007). Although they belong to very different (or even opposite) schools of thought, they both advocated the reestablishment of democratic rule that would happen in the late 80 s, building the foundations of the current Brazilian democracy.

Following a period of 21 years of military rule, a period of greater political liberty began with the restoration of civil rights and amnesty to political prisoners. The work of João Baptista de Oliveira Figueredo was of relevance for this because he continued to push for the reestablishment of democracy, despite the strong opposition of the right-wing military that was looking to remain in power by any means necessary ${ }^{5}$ (Del Priore \& Venancio, 2010). The road to democracy began with the accession of Tancredo Neves in 1985. His unexpected demise before even taking the oath of office left José Sarney in charge of the state, and he worked to achieve the transition towards democratic rule (Sader, 2010).

4. Middle powers are characterized by three variables: a manifest leadership decision, a perceived international legitimacy of its leadership, and material capacity to sustain it (Dewitt \& Christie, 2007).

5. One of the most outstanding facts that made the military's desperation was the bomb-rigging of a vehicle in which a sergeant and a colonel were travelling. After an investigation, it was possible to conclude that the act was aimed at blaming the left so as to classify political rivals as terrorists (Del Priori \& Venancio, 2010). 
The next step was the reestablishment of democracy and the search for new means of economic development. Soaring foreign debt, galloping inflation and an overwhelming economic stagnation all made this an extremely challenging proposition. Meanwhile, the international economic system was undergoing deep transformation, including the promulgation of the so-called Washington Consensus. This consensus led Latin American countries towards free market economies and fiscal reforms that, in some cases, had unwanted consequences and, in others, provided useful bases for economic growth. The latter is the case of Colombia and Brazil. One of the most important reforms of the 90s in the Brazilian case was the Plan Real ${ }^{6}$, which was successful in reducing and stabilizing inflation levels. In fact, it was one of the main drivers of the election of Cardoso in 1994 (Matosso, 2010). Although it was in line with the Washington Consensus, it went beyond its prescriptions and was adapted to Brazil's reality, which accounts for its success. Other countries, which simply implemented the Consensus' ideas as were proposed by U.S. policy makers (like Argentina), were unsuccessful and prompted new economic downturns.

Nevertheless, there was a turning point in the traditional neoliberal process and in Brazil's foreign policy in 2002 with the presidency of Luiz Inácio Lula da Silva. His government must be analyzed from two perspectives: the domestic and the international. Regarding the first, the first step that Lula took was the implementation of diverse macroeconomic adjustments aimed at the stabilization of the monetary, fiscal and exchange rate situations. The result was seen shortly after the reforms: in 2004, the exchange rates were decreasing and exports, the minimum wage and credit concessions were increasing. This would be a constant in Lula's administration (Barbosa \& Pereira de Souza, 2010).

Regarding the international situation of Lula's term, it is important to note the relevance that foreign policy and the positioning of Brazil as a regional leader assumed for the president. This would lead Brazil to consolidate regional integration processes such as UNASUR. The analysis of this historical process will allow a better understanding of how the internal and external situations were determinants in the evolution and adaptation of the Brazilian security models.

\section{BRAZIL'S SECURITY MODELS}

In the historical development of Brazil it is possible to observe two theoretical positions in the country's foreign policy security model. On the one hand, realist practices aimed at entrance to the international arena via hard power, reflecting the doctrines implemented by the military during the dictatorship (1964-1984). On the other hand, practices of institutional liberalism

6. The Plan Real was proposed and developed by Fernando Henrique Cardoso and a team of young reformers that aimed at modernizing Brazil's economy through inflation control and growth facilitating measures (Roett, 2010). 
since the return to democracy, especially in the two periods of the Lula administration have reaffirmed the importance of intergovernmental organizations as discussion forums and mechanisms for conflict resolution (Costa, 2004).

The realist practices were developed through the model of national security, whose aim was the safeguard of the country (Bonilla \& Cepik, 2004). Taking the School of Copenhagen as a framework of reference, the referent object was focused on the preservation of the territorial integrity. National security was conceived exclusively by the military, which meant that both military and economic agendas were rendered through the military lens. Thus, Brazil's economic development was based on the consolidation of military hegemonic power (Sánchez, et al., 2005).

After the restoration of democracy, Cardoso led the country towards a new model that, during his eight years in office, enabled the institutional consolidation and the full reestablishment of civil rights. In addition, the new model re-framed relations between civil society and the military. In combination, Cardoso's measures can be defined as democratic security. ${ }^{7}$ The comparative analysis section below will contrast the national security model with the current security model in Brazil.

The formulation of the national defense policy, adopted in 1996, profoundly changed the institutions inherited from military rule. In addition to the creation of the Ministry of Defense, which tied the military to civilian rule, the precepts of a civilian order were strengthened and the peaceful resolution of controversies became the rule, leaving force as a last measure in cases of defense necessity (Costa, 2004). Alongside the reestablishment of democracy, the historical differences with Argentina waned and this allowed Brazil to accomplish two things: first, it acknowledged that there was no external enemy and second, it redirected its security objectives towards the Amazon.

With Lula's ascent, there was a turning point in Brazil's policy that impacted all economic, social and political structures, as well as the consolidation of the country's objective of projecting itself as a middle power in the global system. Lula changed the neoliberal policies of his predecessor by revaluating the government's priorities in terms of socioeconomic development and, consequently, reforming the security model. One of the most relevant characteristics of the Lula administration was the increase in health and education spending, a clear application of human security (Cervo, 2010).

Lula prioritized achieving social and economic justice throughout the world in his foreign policy. Thus, he showed Brazil's solidarity in the combat against poverty and hunger in the framework of multilateralism, speaking of it in diverse venues like the G8, the World Economic Forum

7. Not to be confused with the democratic security policy proposed by the Uribe Vélez administration in Colombia. 
and the UN General Assembly (Rodriguez, 2005). His speeches before international audiences were replicated domestically, which led him to consolidate a new paradigm for Brazil in the 21st century: human security and development.

Now that the Brazilian case has been presented, the following section focuses on Colombia.

\section{EVOLUTION OF SECURITY IN COLOMBIA A RETROSPECTIVE VIEW}

Critiques of Colombian foreign policy converge on the analysis of its high fragmentation, weak planning and reactive nature. However, little has been written about the management and application of one of its most important concepts in current international relations: security. Among the few to address the topic are Tickner (2007) and Cardona (2011), who discuss the securitization of Colombia's foreign policy in the $21^{\text {st }}$ century, which will be debated below.

In the early 1990s, the country began a process of institutional transformation that positively affected all functional areas of the state. This was because of the new legal framework that came with the 1991 political constitution. With the ascension of César Gaviria Trujillo to the presidency, the implementation of a neoliberal economic order was combined with a profound reform in domestic policy areas such as those regarding drug trafficking, violence and human rights (Vargas-Alzate, 2009) and these topics would modify the essence of the country's foreign policy, as they became the foundation of its application.

The administrations of Gaviria Trujillo (1990-1994) and Samper Pizano (1994-1998) shared a security stance in that they both focused on advances in the abovementioned topics. Thus, security was being thought of in terms of traditional defense and military strengthening. Francisco Leal Buitagro (2004:175) argues that the "Gaviria Trujillo administration advanced important reforms in terms of defense and national security, modified the relationship between the military and the civil institutions of the state and developed a novel security strategy, which was termed Estrategia nacional contra la violencia (national strategy against violence)".

However, the security model put in place by the Gaviria Trujillo administration maintained the traditional tendency of strengthening the military apparatus of the country. With the arrival of Andrés Pastrana Arango to the presidency in 1998, this line of thought continued. Moreover, it can be argued that the Pastrana Arango administration presented an improvement in the military forces compared to its predecessor, which indirectly allowed the weakening of the institutions because of the judicial trouble associated with the Proceso $8000 .{ }^{8}$

8. Ernesto Samper Pizano was investigated during his presidency for supposed funding of his presidential campaign by the Cali drug cartel. 
Pastrana Arango advanced important processes that drove the reform of the Colombian armed forces (Vargas \& Patiño, 2006). However, his mistakes in managing the peace dialogues with the Armed Revolutionary Forces of Colombia (FARC) gave the impression of institutional weakness and transmitted a negative image of the state's administrative processes.

The state's foreign policy was formulated in line with the needs of some external actors, in which the U.S. stands out as the prime external stakeholder. Indeed, the reform of the armed forces was accompanied by two instruments linked to the country's Washington-oriented foreign policy: Plan Colombia and the Regional Andean Initiative (Iniciativa Regional Andina) (Leal, 2004), both approved by the U.S. congress. ${ }^{9}$ These instruments generated increased dependence of Colombia on the US. Although the Samper Pizano administration was shunned by the U.S., the arrival of Pastrana Arango presented a return to the traditional alignment with that country.

\section{THE $21^{\text {ST }}$ CENTURY}

Plan Colombia was understood as a mechanism for strengthening defense and security. It defined the country's foreign policy in two areas: first-and contrary to most Latin American countries, which were moving away from the United States' sphere of influence-it brought Colombia's foreign policy in line with Washington (Tickner, 2007). For Colombia, this was a return to the old concept of Respice Polum. ${ }^{10}$ Moreover, as Leal Buitrago (2004) explains, the agreement between the U.S. and Colombia served as an instrument of U.S. strategic interest via military intervention against guerilla groups.

Second, Colombia's foreign policy was securitized. Several academics have indeed concluded that this is a defining characteristic of the Uribe Vélez administrations (2002-2006, 2006-2010). It is important to emphasize the work of Tickner (2007), Carvajal (2009) and Cardona (2011) here. Carvajal actually refers to the "terrorization" of Colombian foreign policy after the attacks on the World Trade Center in 2001, when Colombia's internal conflict was conflated with the global war on terror.

As things were, security was maintained as the most important topic in the country's foreign policy. Plan Colombia acted as a catalyst of two processes that scholars such as cited have coined the securitization and narcotization of Colombia's foreign policy. Both are explained

9. Plan Colombia should be understood as a direct assistance program between Colombia and the United States whose aim is to create and implement an antinarcotic strategy that would be useful for the institutional restructuring of the Colombian state.

10. This was a principle applied in the study of Colombia's foreign policy and its first use is attributed to the president Marco Fidel Suárez (1918-1922), who affirmed that Colombia should reinforce its links with the emerging global power. Further information can be found in Drekonja (1983). 
as inadequate deviations from the exercise of global interaction (Carvajal, 2009), that is, a wrong way to implement the country's diplomacy. Securitization was the hallmark of Uribe's democratic security policy which emphasized the strengthening of the armed forces over all other objectives. The process of securitization also generated non-conformity and fear in the region. Not only that, the narcotization process meant that the war on drugs became Colombia's main topic of interaction with the rest of the world.

Along these lines, a relevant topic of the second Uribe Vélez administration (2006-2010) was the signing of the "Complementary agreement for cooperation and technical assistance in defense and security" between the U.S. and Colombia. This agreement was declared unenforceable by the Colombian Constitutional Court in August, 2010. It also became a major issue for the region because other governments saw it as an intervention tool of the U.S., as it would be possible for it to use Colombian territory to exert a direct influence over Latin America and the Caribbean.

Nevertheless, the reactions of regional governments against the agreement were not monolithic: while Argentina and Brazil tried to use the crisis as a means of establishing a South American doctrine on the military presence of foreign powers in the region as well as a means of preventing the exit of Colombia from Unasur; Venezuela denounced Colombia as an outsider allied with the 'Empire' bent on undermining South American unity (Borda, 2012). Regional opposition to the agreement was underestimated by the Colombian government, which found itself in the middle of a nearly unprecedented diplomatic and political crisis.

As such, and based on Tickner, Cardona, Leal, and Carvajal, it is possible to conclude that the Uribe Vélez administration continued the strengthening of Colombia's defense schemes begun under Pastrana Arango, while, at the same time, tried to link domestic security issues to international issues (i.e. the war on terror) under the auspices of democratic security. The figures obtained from the Correlates of War Project (Singer, 1987, version 4.0) clearly reflect the militarization of Colombia. Around 2000, the country had 152,000 soldiers, whereas by 2005 the number had reached 207,000. In 2009, according to Poderes Armados (2010), Colombia had 285,220 soldiers and a military expenditure of 6.15 billion USD.

It is important to note that, because of the strong relations between Washington and Bogotá, Colombia was reluctant to commit to the South American Defense Council led by Brazil. It was only at the last moment possible, in June, 2008, that the Colombian government accepted to become a member (Moreira, 2010). This was another factor that made many South American governments view agreements between Colombia and the U.S. as a possible threat.

However, with the ascension of Juan Manuel Santos to the presidency, Colombia's foreign policy took a new path. With his foreign relations minister, Maria Ángela Holguín, president Santos has moved Colombia closer to the region and reduced the intensity of issues of security (understood in terms of defense). Approaches to regional leaders have put Colombia in a position where dialogue with UNASUR members can now be fluent and direct. Saber rattling toward Ecuador 
and Venezuela has decreased at the same time that commercial, political, social and cultural links with these nations have come to surpass military development in importance. Nevertheless, Colombia's militarism is not easily left aside, especially given the country's internal conflict and institutional fragility. Moreover, the starting of peace dialogues with the FARC means that there will be further challenges to Colombia's strength ahead.

In particular, the qualities which enable the Colombian state's survival and advance in the strengthening of state institutions are the same obstacles it faces in implementing the new concepts of security. So far, human security, as a multidimensional approach, has not been linked to the application and development of security in the country's foreign policy. Though human security may be considered a challenge being addressed, it is not yet established in the country's security strategy.

The next section presents a parallel between the security models applied in the two analyzed cases. In both states (Colombia and Brazil) there is a process of democratic consolidation. However, in the specific case of Brazil, and given the circumstances of the dictatorship period, the impact of democratization has fostered better conditions for this state than that of Colombia, especially where the application of human security is concerned. In the case of Colombia, it is necessary to take into account that the dynamics of the internal conflict forces it to maintain a traditional stance regarding security, a limitation that Brazil does not have.

What follows is a quantitative comparison between both countries with the objective of deepening the analysis and verifying the findings presented so far.

\section{COMPARATIVE ANALYSIS OF COLOMBIA AND BRAZIL}

The analysis developed thus far shows some transformations in terms of defense and security in both countries. On the one hand, Brazil advances towards a situation of less militarization and is more and more focused on the postulates of human security. On the other hand, Colombia continues with a militarization process focused on the war on drugs and the war against illegal armed groups within the country. This section develops a quantitative approach with the aim of confirming or contrasting the application of the concept of human security with the secondary sources used in the sections above. Figure 1 compares the number of soldiers of Colombia and Brazil with the South American average.

Figure 1 confirms Brazil's road towards demilitarization described above. Moreover, it shows that such is the region's general tendency, insofar as the regional average, like Brazil's, is declining. The great reduction in this indicator between 1987 and 1988 is also noteworthy, and coincides with the third wave of democracy. The Colombian case, on the contrary, shows a steep increase between 1988 and 1992, explained by the war against the drug cartels in Bogotá, Medellín and Cali. 


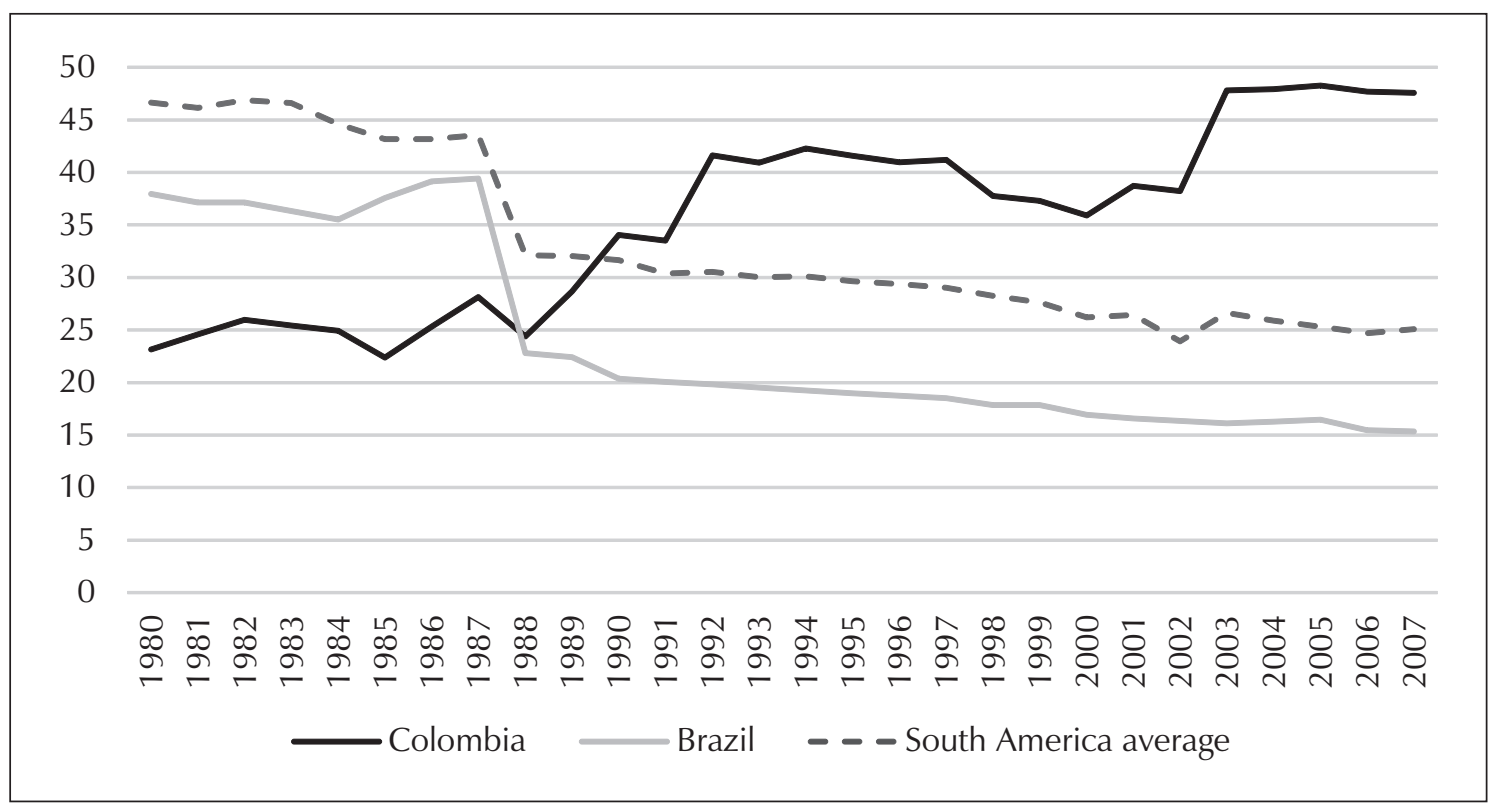

Figure 1. Soldiers per 10,000 inhabitants, 1980-2007

Source: made by the authors based on Singer (1987, version 4.0).

From that year onward, the number of soldiers per inhabitant in Colombia remains stable until 1997, when the proportion diminishes until the year 2000 (the first half of the Pastrana Arango administration). It then starts to increase again and between 2002 and 2003 there is an increase of $25 \%$. This new growth in the proportion is linked to the implementation of Plan Colombia, which reflects the cited topic of the securitization of Colombia's foreign policy through the implementation of the policy of democratic security of the Uribe Vélez administration. Thus, this ratifies the works of Tickner (2007) and Carvajal (2011).

In addition to the analysis of the quantity of soldiers in proportion to the total population, it is important to study the quality of the army of each country. The military quality is an indicator that allows the comparison between armies and between military expenditures because it is a relativized variable. The following figure shows the military quality in South America in comparison with the two studied cases.

Figure 2 shows that in 1990 the region, and specially Brazil, begins to increase its military quality. However, the military quality of Brazil suffers a pronounced decrease towards the end of the $20^{\text {th }}$ century, but starts to increase rapidly and continuously in 2004. The negative variation of Brazil can be explained by the impact of the international economic crisis of the 90s (the Asian crisis) and the positive variation, in general, is a sign of the great emphasis that Brazil has put in the modernization of its armed forces. 


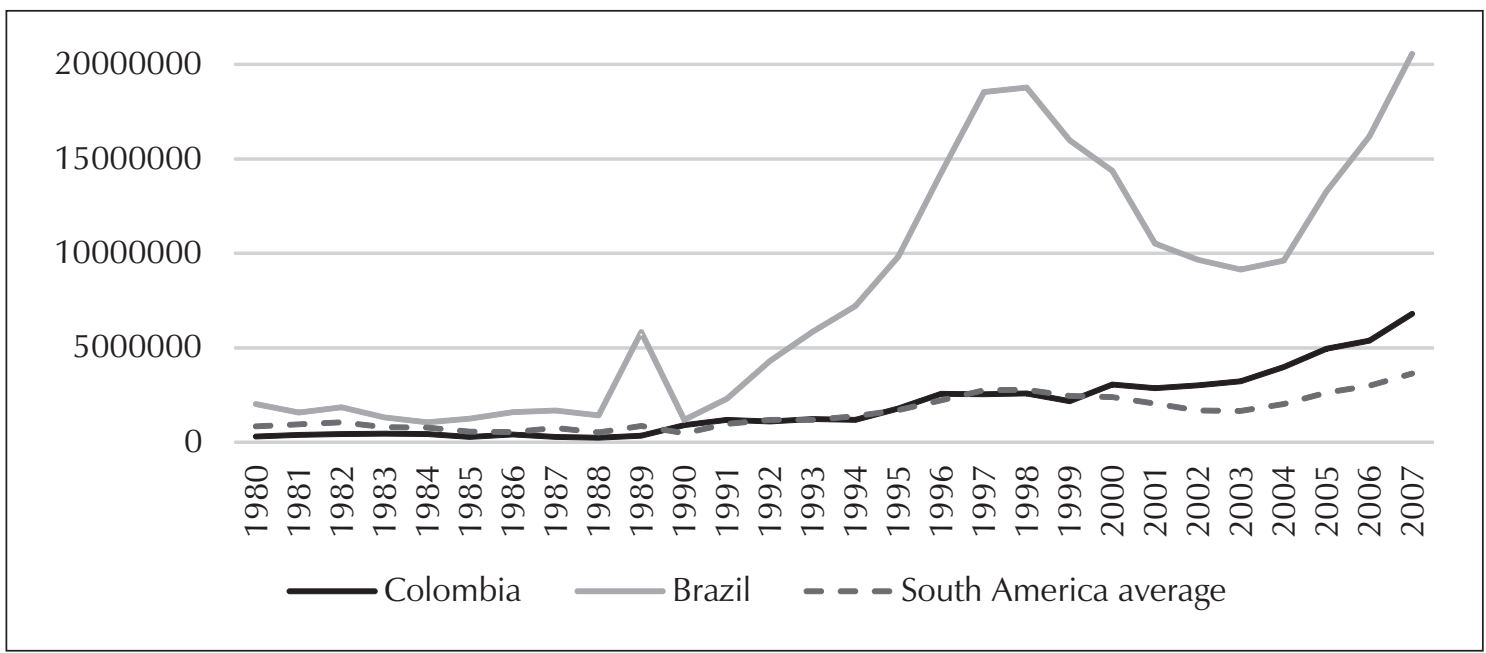

Figure 2. Military quality (dollars invested per soldier), 1980-2007

Source: made by the authors based on Singer (1987, version 4.0).

In the case of Colombia, the military quality has continuously increased since 1989 (with the exception of 1999, year in which it diminishes slightly). The impact of Plan Colombia is noteworthy. In particular, in 2003 the increase in military quality becomes more pronounced, which coincides with the policy of democratic security and the increase of the proportion of soldiers per inhabitant.

So far, the statistical component of security has been analyzed in classical or traditional terms (defense). Through the following figures, the analysis is oriented towards the application of the concept of human security in both cases and their statistical results. Figure 3 compares the military expenditure with the social spending in Colombia and Brazil.

In both cases, social spending is far higher than military expenditure. Moreover, if spending in education and health were presented separately, they would both still be higher than military expenditure. Over the past few years, social spending in Colombia and Brazil has become almost identical (in terms of GDP percentage). However, this spending for the Colombian case fell from almost $12 \%$ of the GDP at the end of the $20^{\text {th }}$ century and hasn't recovered to this level, although it has begun increasing continuously since 2008. The great difference between 1999 and 2000 could be explained by the impact of the Asian crisis and the security situation during the Pastrana Arango administration. Brazil's social spending, on the other hand, has been increasing since the year 2000, yet the yearly changes are slight.

According to the above, Brazil is applying the concept of human security in its policies because of the constant increase in the spending with the objective of improving the population's 


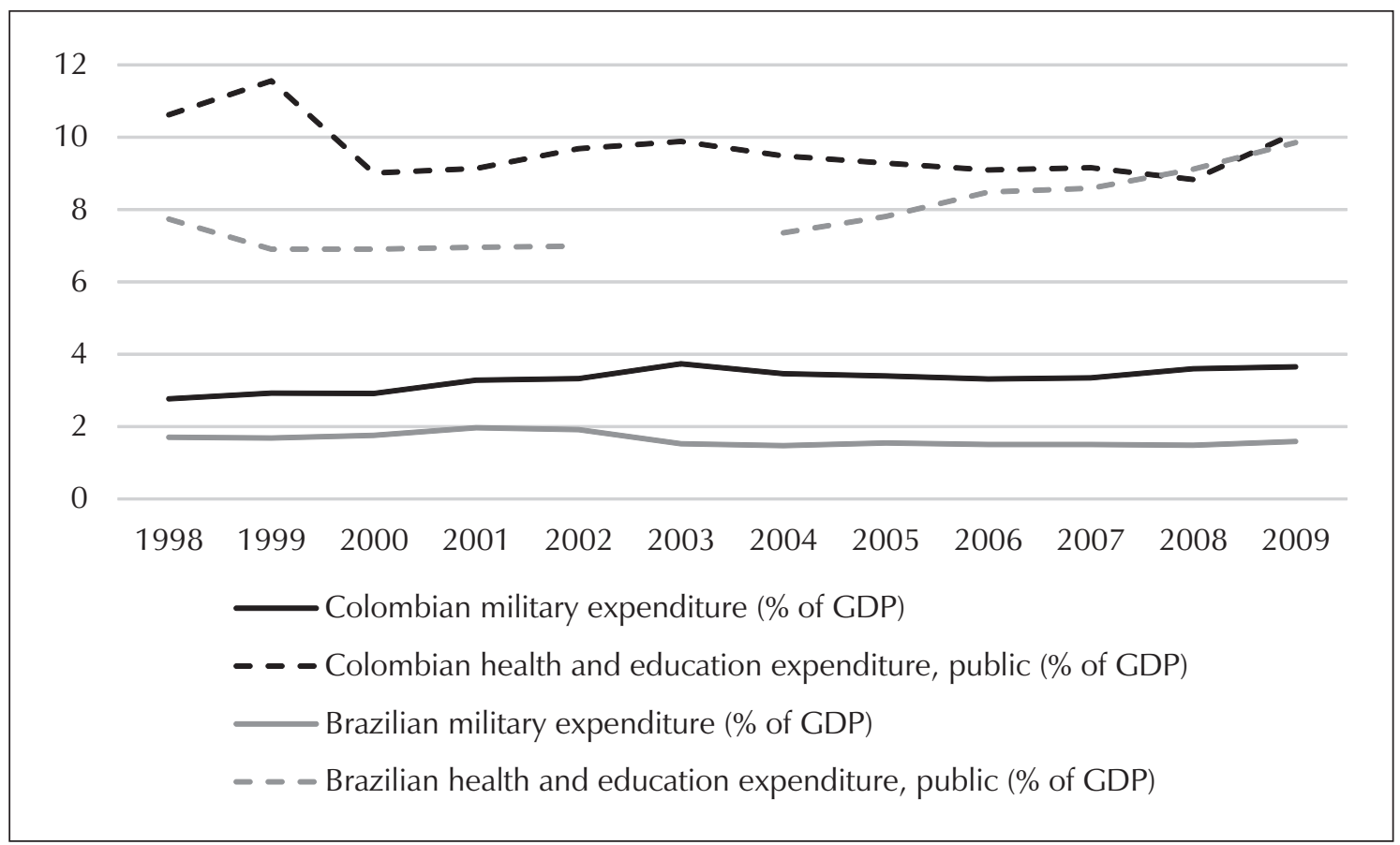

Figure 3. Military expenditure and social spending (health and education) as percentage of GDP in Colombia and Brazil, 1998-2009

Source: made by the authors based on World Bank (2012).

quality of life. However, this country's social spending is quite similar to Colombia's even though the Brazilian GDP is far greater than the Colombian (which makes the spending higher in absolute terms), the population and territorial extension of Brazil is also far greater. Regarding Colombia, there is no diminishing of military expenditure but there is one in social spending, which suggests that the traditional security objectives remain the most important. However, the increase from 2008 to 2009 in social spending shows that there is also a tendency towards ensuring the quality of life of the Colombians, which is why Colombia is also on its way, although slower than Brazil, to the implementation of the concept of human security in its policies.

But how much can the figure above really tell? In both countries social spending is higher than military expenditure, and in both cases the former is increasing. Moreover, high social spending doesn't necessarily mean that the governments are striving for better life conditions. Thus, the figure above will be contrasted with human development in the region. Figure 4 shows the Human Development Index for South America. 


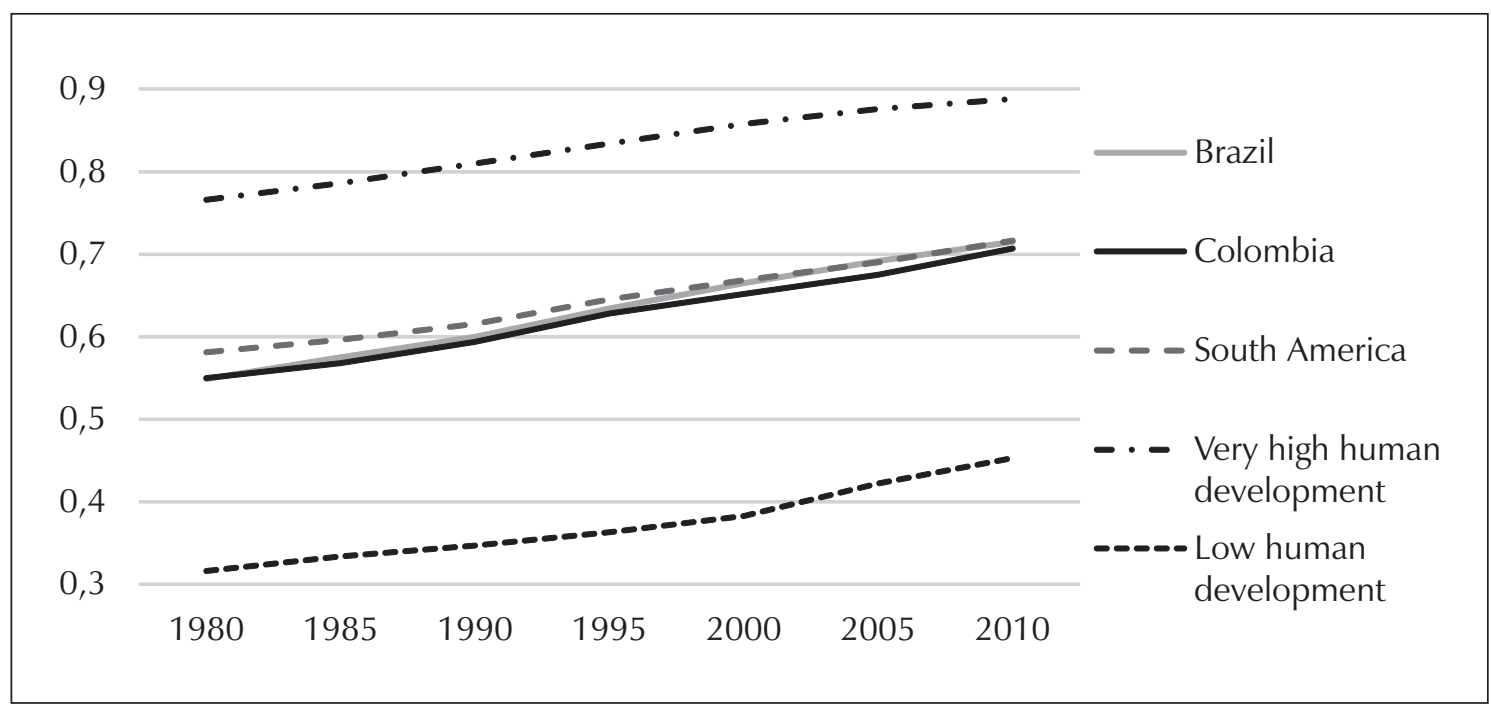

Figure 4. Human Development Index in South America, 1980-2010.

Source: made by the authors based on UNDP (2012).

As can be seen, both countries are in constant improvement of their human development. What is interesting is that both are below the regional average and the score of Colombia is almost identical to Brazil's. The breach between South America and the most advanced countries in the world is, however, quite large. Thus, despite the evidence that the two countries are headed towards the implementation of human security (especially Brazil), the advance has been very slow and there is still a long road ahead.

\section{CONCLUSIONS}

It becomes clear that Brazil has advanced through a gradual demilitarization that began with the democratization of the country. Although its military expenditure is still very high, this corresponds to modernization programs that follow the restructuring of its defense schemes in order to meet the current demands of the international system and its objectives of international leadership. Colombia, on the other hand, presents the opposite trend, oriented towards militarization. According to the statistics presented here and the analysis of the country's internal situation, which involves an armed conflict recognized by the current government, the country still applies a traditional security model, fundamentally understood in terms of national defense.

Thus, it is necessary to point out that the country possesses an internal threat and that, because of the critical situation of 2008, it also perceived to be an external threat in some of its neighbors. Brazil, on the contrary, does not perceive such threats, neither inside nor outside 
its borders, as it does not identify any military rivals within or without its borders, although organized crime has become an increasing concern in cities such as Rio de Janeiro, Sao Paulo and Belo Horizonte.

This work has proposed, as a starting point, a revision of the evolution of the concept of security in the two studied cases. It is noticeable that human security has assumed increased importance in development plans and state programs worldwide. In this respect, though more for Brazil than for Colombia, the state of the art in the existing literature evidences advances in the change of the historical tendency of security as defense towards human security. Nevertheless, this work has shown that the distances between the two countries in terms of the application of human security is not as great as expected. In this regard, future planning in both countries needs to view human security as a serious concern in the design and execution of public policies. In order to do so, a better understanding about each country's current state of affairs, seen through the lens of human security, is warranted, and this may come from more academic work on the subject, and we propose several research venues for further studies below.

The study presented here is limited, however, in that it doesn't fully address the extent of human security, as it is a very broad concept. Thus, future works should focus on using variables that target each of the seven human insecurity sources, as defined by the UNDP. Another line of research could focus on comparative analysis using other variables, such as number of policemen per inhabitant, crime rates, number of homicides per inhabitant, among others that may shed more light on how secure South Americans are. Future research should also focus on specific regions within each these countries in order to fully assess human development, as the concept of human security demands micro-level analysis. Comparative analysis should also be expanded to other countries in South America in order to clearly comprehend the region's security situation.

\section{REFERENCES}

Barbosa, N. \& Pereira de Souza, J. (2010) “La inflexión del gobierno de Lula: política económica, crecimiento y distribución". In Sader, E. \& García, M. Eds. Brasil entre el pasado y el futuro, pp. 71-118. Buenos Aires: Capital intellectual.

Baylis, J. (2008) "The concepts of security in International Relations", in Brauch, H. et al. Eds. Globalization and environmental challenges: reconceptualizing security in the $21^{\text {st }}$ century, p. 495-502. Berlin: Springer-Verlag.

Bonilla, A. \& Cepik, M. (2004). "Seguridad andino-brasileña: conceptos, actores y debates". In Cepik, M. \& Ramirez, S. Eds. Agenda de Seguridad Andino-Brasileña: primeras aproximaciones. Pp. 37-94. Bogotá: FESCOL. 
Borda, S. (2012). Desafíos y oportunidades de la Unión de Naciones Suramericanas - UNASUR -. Documentos Cries, № 18, 2012. Published in cries.org [http://www.cries.org/wp-content/ uploads/2012/04/DOC18-web.pdf]. Accessed on: 09/11/2012.

Buzan, B. (1983) People, states and fear. The national security problem in international relations. University of North Carolina Press: USA. 262 p.

Buzan, B. \& Wæver, O. (2003). Regions and Powers The Structure of International Security. Cambridge: United Kingdom. 564 p.

Cardona, D. (2011). Colombia, una política exterior en transición. Bogotá: FESCOL, 469 p.

Carvajal, L. (2009). La política exterior de la administración Uribe: entre el mundo y la parroquia. Política colombiana, № 1, 2009, p. 31-42.

Cepik, M. \& Ramirez, S. Eds. Agenda de Seguridad Andino-Brasileña: primeras aproximaciones. Bogotá: FESCOL, IEPRI. 517 p.

Cervo, A. (2010). brazil's rise on the international Scene: brazil and the World. Revista Brasileira de Política Internacional, 7-32.

Christie, R. (2010). "Critical voices and human security: to endure, to engage or to critique?" Security Dialogue, Vol. 41, № 2, 2010, p. 169-190.

Costa, A. (2004). "La agenda de seguridad de Brasil". In Cepik, M. \& Ramirez, S. Eds. Agenda de Seguridad Andino-Brasileña: primeras aproximaciones, pp. 145-174. Bogotá: FESCOL, $517 \mathrm{p}$.

De Maio, J. (2006). "Managing civil wars: an evaluation on conflict prevention strategies in Africa". World Affairs, Vol. 168, № 3, 2006, p. 131-144.

Del Priore, M. \& Venancio, R. (2010). Uma breve história do Brasil. Sao Paulo: Planeta, 319 p.

Dewitt, D. \& Christie, R. (2007). "Los poderes medios y la seguridad regional". In Tokatlian, J. Ed. India, Brasil y Sudáfrica. El impacto de las nuevas potencias, pp. 55-96. Buenos Aires: Libros del Zorzal, 240 p.

Drekonja, G. (1983). Retos de la política exterior colombiana. Bogotá, Fondo Editorial Cerec. 232 p.

Flemes, D. \& Nolte, D. (2010). "Alianzas externas para armamento y defensa. Una nueva dimensión en la agenda de seguridad latinoamericana". Foreign Affairs Latinoamerica, Vol.10, № 1, 2010, p. 2-13. 
Fontes, V. (2007). "La democracia en Brasil: aprendizaje y mimetismo". In Ansaldi, W. Ed. La democracia en América Latina, un barco a la deriva, pp. 365-386. Buenos Aires: Fondo de Cultura Económica de Argentina. 582 p.

García, B. (2010). "Doctrinas, actores e instituciones: perspectivas jurídicas en el tema de seguridad en América Latina." In Vargas, A. (Ed.) Seguridad en democracia: un reto a la violencia en América Latina, pp. 25-42. Buenos Aires: CLACSO.

Hurrell, A. (1998). "Security in Latin America". International Affairs, 74, 3, 529-546.

Inglehart, R. \& Norris, P. (2012). "The four horsemen of the apocalypse: understanding human security". Scandinavian Political Studies, Vol. 35, № 1, 2012, p. 71-96.

Kelly, R. (2007). "Security theory in the new regionalism". International Studies Review, Vol. 9, № 2, 2007, p. 197-229.

Kegley, Ch. \& Raymond G. (2011). The global future: a brief introduction to world politics. Wadsworth Inc Fulfillment: Boston, MA, USA. 438 p.

Leal, F. (2004). "La seguridad en el gobierno de Álvaro Uribe Vélez". In Cepik, M. \& Ramirez, S. Eds. Agenda de Seguridad Andino-Brasileña: primeras aproximaciones, pp. 175-242. Bogotá: FESCOL.

Lemke, D. (2010). "Dimensions of hard power: Regional leadership and material capabilities". In D. Flemes, Regional Leadership in the global system: Ideas, interest and strategies of regional powers. Emgland: Ashgate Publishing Limited. 394 p.

Matosso, J. (2010). "El Brasil heredado". In Sader, E. \& García, M. Eds. Brasil entre el pasado y el futuro, pp. 41-68. Buenos Aires: Capital intelectual, 256 p.

McComarck, T. (2008). "Power and agency in the human security framework". Cambridge Review of International Affairs, Vol. 21, № 1, 2008, p. 113-128.

Miller, B. (2005). "When and how regions become peaceful: potential theoretical pathways to peace". International Studies Review, Vol. 7, № 2, 2005, p. 229-267.

Moreira, Á. (2010). "Consejo Sudamericano de Defensa: hacia una integración regional en defensa". In Vargas, A. (Ed.) Seguridad en democracia: un reto a la violencia en América Latina, pp. 159-173. Buenos Aires: CLACSO.

Oberleitner, G. (2005). "Human Security: a challenge to International Law?" Global Governance, Vol. 11, № 2, 2005, p. 185-203. 
Polverini, E. (2010). Política, defensa y seguridad suramericana. Working paper del Centro Argentino de Estudios Internacionales, № 41, 2010. Published in caei.com.ar [http://www. caei.com.ar/es/programas/dys/41.pdf]. Accessed on: 06/20/2012.

Rodriguez, A. (2005). "Brasil, nueva superpotencia". Política Exterior, Vol. 19, № 107, 2005, p. 113-123.

Roett, R. (2010). The New Brazil. Washington D.C.: Brookings Institution, 178 p.

Sader, E. (2010). "Brasil, de Gétulio a Lula". In Sader, E. \& García, M. Eds. Brasil entre el pasado y el futuro. Pp. 17-37. Buenos Aires: Capital intelectual, 256 p.

Sánchez, R. et al. (2005) El círculo de Colombia. Brasil, Ecuador, Panamá, Perú y Venezuela. Bogotá: Universidad del Rosario, 244 p.

Singer, J. (1987). "Reconstructing the Correlates of War Dataset on Material Capabilities of States, 1816-1985." International Interactions, № 14, 1987, 115-132. Version 4.0 (2010).

Thomas, N. \& Tow, W. (2009). "The utility of human security: sovereignty and humanitarian intervention". Security Dialogue, Vol. 33, № 2, 2009, p. 177-192.

Tickner, A (2004). "La securitización de la crisis colombiana: bases conceptuales y tendencias generales". In: Colombia Internacional, 60, 12-35.

(2007). “Intervención por Invitación: Claves de la política exterior colombiana y sus debilidades". Colombia Internacional, № 65, 2007, p. 90-111.

UNDP (1994) Informe sobre Desarrollo Humano 1994: un programa para la Cumbre Mundial sobre Desarrollo Social. Published in un.org [http://hdr.undp.org/es/informes/mundial/ idh1994/]. Accessed on: 07/19/2012.

(2012) International Human Development Indicators, published in un.org [http://hdr. undp.org/en/statistics/]. Accessed on: 07/19/2012.

Vargas, A. \& Patiño, C. (2006). Reforma militar en Colombia: contexto internacional y resultados esperados. Medellín: UPB, 230 p.

Vargas-Alzate, L. (2009). "Búsqueda de vínculos teóricos de las Relaciones Internacionales en el planteamiento y aplicación de la política exterior de Colombia entre 1974 y 2008". In Tamayo, R. Ed. Relaciones Internacionales en contexto Pp. 99-150. Medellín: Fondo Editorial EAFIT.

World Bank Group. (2012). World Databank, published in worldbank.org [databank.worldbank. org]. Accessed on: 09/06/2012. 